\title{
Assessment of Mangrove Ecosystem Conditions in Coastal Area Mamuju Regency, The Province of West Sulawesi, Indonesia
}

\author{
Qadarisma* $^{*}$ Muh Hatta* ${ }^{* *}$, Supriadi Mashoreng ${ }^{* *}$ \\ * Study Program of Integrated Coastal Resource Management, \\ Faculty of Marine Science and Fisheries of Hasanuddin University, Makassar, South Sulawesi, Indonesia \\ ${ }^{* * *}$ Department of Marine Science, Faculty of Marine Science and Fisheries \\ Hasanuddin University, Makassar, South Sulawesi, Indonesia \\ (Correspondence Author: qadarismay@gmail.com) \\ DOI: 10.29322/IJSRP.11.07.2021.p11556 \\ http://dx.doi.org/10.29322/IJSRP.11.07.2021.p11556
}

\begin{abstract}
The coastal area in Mamuju Regency, West Sulawesi Province has a very large mangrove ecosystem potential if it is utilized and managed properly to improve the welfare of the community. Therefore, in sustainable management efforts, it is necessary to know the condition of mangrove forests in the coastal area of Mamuju Regency. Based on this, a research was conducted to determine the condition of the mangrove ecosystem, namely the density of mangroves with the line transect method and the line transect plot in the form of a square with a size of $10 \mathrm{~m} \times 10 \mathrm{~m}$, and the mangrove canopy cover with the hemispherical photography method, then the photos were analyzed using a device. ImageJ software and Microsoft Excel. This research was conducted from July to October 2020, the research locations were at 5 stations located in the Bebanga Village, Tadui Village and Bambu Village of Mamuju Regency, West Sulawesi Province, Indonesia. The results of the measurement of environmental parameters indicate that environmental conditions support the existence of mangroves. From the identification of species found 11 species of mangroves from 5 families. Analysis of the density and percentage of mangrove canopy cover showed that at station 1 (Village of Bebanga) a density of 1633 trees/ha and a cover of 84.14\%, station 2 (Village of Bebanga) a density of 617 trees/ha and a cover of $48.24 \%$, station 3 (Village of Tadui) a density of 1100 trees/ha and a cover of $82.64 \%$, station 4 (Village of Bambu) a density of 1511 trees/ha and a cover of $76.58 \%$, station 5 (Village of Bambu) a density of 540 trees/ha and a cover of $49.23 \%$.
\end{abstract}

Keywords: density, canopy cover, mangrove, Mamuju

\section{INTRODUCTION}

Mangrove forests are the main ecosystem that supports important life in coastal and marine areas. Mangroves are considered one of the most productive ecosystems on the planet. Mangrove ecosystems have an important role both ecologically and biophysically as well as in the socio-economic community even for millions of people in the tropics and subtropics (Atkinson et al., 2016). Ecological functions include playing a role in nutrient cycles, soil formation, wood production, fish spawning areas (Sofian et al., 2019). Physically, mangroves can function to keep the coastline stable, protect the coast from waves, prevent abrasion, protect the coast from the threat of a tsunami, and act as a buffer area (filter) and (Septinus et al., 2017; Kamal \& Haris, 2014). In addition, mangroves can also neutralize water pollution (Lasibani \& Kamal, 2010) and are also flood controllers. Economically, the existence of mangrove ecosystems is closely related to the level of fishery production and plays an important role in the development of coastal fisheries (Utomo et al., 2017) in addition to supporting the livelihoods of coastal communities (Sofian et al., 2019; Polidoro et al., 2010).

The mangrove ecosystem is one of the most endangered ecosystems in the world, which is under constant pressure from encroachment and land degradation, mainly driven by human activities (Ghosh et al., 2015). Every year the mangrove ecosystem in Indonesia continues to decrease in area due to conversion for various purposes. The data shows that within 17 years (1982-1999) the mangrove ecosystem in Indonesia has decreased in area of about 54\% or 
3.2\% per year. Mangrove area in 1982 was 5.209 .543 ha, in 1987 it was 3.235 .700 ha, in 1993 it was 2.496 .185 ha, in 1999 it was 2.346.414 ha (Sofyan, 2001), and based on data from One National Mangrove Map, mangrove area in 2019 is $3.311 .207,45$ ha. The decline in mangrove area that occurred nationally was not much different from what happened in Mamuju Regency, the data of Blue Forest in 2015 showed that within a period of 35 years (in 1980-2015) there was a decrease in mangrove area of around 767,61 ha (62\%) in Mamuju Regency from the total decrease was about $5.110,76$ ha $(66 \%)$ in the entire area of West Sulawesi.

Illegal logging and conversion of mangrove forests into ponds are the main factors in the degradation of mangrove forests in Indonesia. The decline in mangrove area causes a decrease in the productivity of the mangrove ecosystem so that the ecological function of mangroves in supporting capture fisheries is also disrupted (Muryani et al., 2011), which consequently will reduce fish capture and the income of fishermen (Mumby et al., 2003). This condition also occurs in West Sulawesi Province where one of the factors causing environmental quality degradation in the coastal and marine areas of West Sulawesi, among others, the low awareness of coastal communities towards the environment, coral reef and mangrove ecosystems and the logging of mangrove forests for pond construction, settlements, the constructions of port and road (Department of Marine and Fisheries of West Sulawesi Province, 2017).

The mangrove area that stretches along the east coast of Mamuju which passes through the Bebanga Village in the District of Kalukku and Tadui Village and Bamboo Village in the District of Mamuju is one of the most extensive mangrove areas in Mamuju Regency. Based on the document of RZWP3K of West Sulawesi Province that the coastal area of Kalukku District and Mamuju District in Mamuju Regency is a mangrove area that is still in the dense category (Department of Marine and Fisheries of West Sulawesi Province, 2017), so that mangroves in this area certainly have a very important role in maintaining the balance of the ecosystem in the area.

Based on the explanation above, it is necessary to know the condition of the mangrove ecosystem in the area in order that the efforts to protect and preserve the mangrove ecosystem can be carried out to support sustainable coastal management in Mamuju Regency.

\section{RESEARCH METHODS}

\section{A. Site and Time of Research}

The research was conducted in the Bebanga Village of Kalukku District, Tadui Village and Bambu Village of Mamuju District, Mamuju Regency, West Sulawesi Province, Indonesia with 5 observation stations, namely stations 1 and 2 in Bebanga Village, station 3 and 4 in Tadui Village, station 5 in Bambu Village (Figure 1) from July to October 2020.

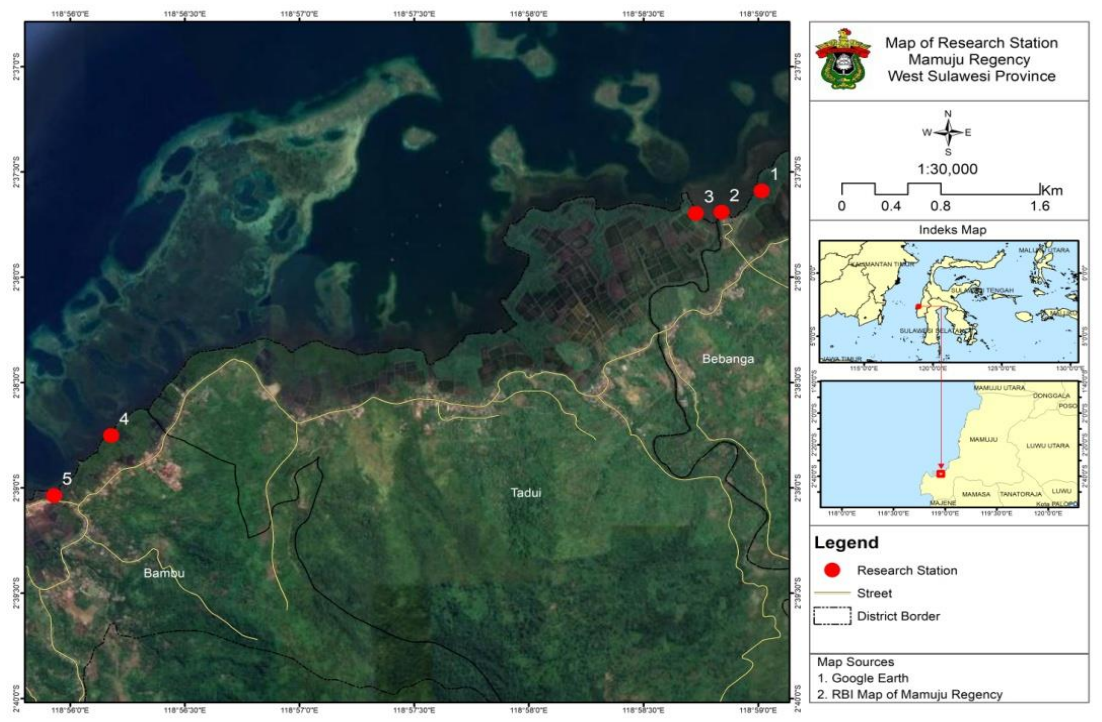

Figure 1. The map of research location

\section{B. Research Procedure}


The method used in this study is a survey method. The types of data collected are mangrove vegetation data including mangrove species, number of individuals, tree trunk circumference and photos of hemispheres/perpendicular to the sky.

Mangrove vegetation data was obtained using the line transect method and the line transect plot, namely by making a perpendicular transect line from sea to land at five (5) observation stations. For each transect, a square plot of $10 \mathrm{~m} \mathrm{x} 10 \mathrm{~m}$ was made. The number of plots at each station is adjusted to the condition of the area and the thickness of the mangrove forest from sea to land in order to provide representation of the mangrove forest. Referring to Dharmawan \& Pramudji (2017) at station 1 of the mangrove vegetation is quite thick and without clear stratification 6 plots are made, station 2 of thin mangrove vegetation and clear stratification is made 6 plots, station 3 of mangrove vegetation thickness $<30 \mathrm{~m}$ is made 3 plots, station 4 of thick mangrove vegetation and clear stratification made 9 plots, station 5 of mangrove vegetation thickness $<30 \mathrm{~m}$ and no clear stratification made 5 plots. Then in each plot, identification of the existing mangrove species was carried out using the mangrove guide book Noor et al. (2012), calculated the number of stands to determine their density using the formula English et al. (1994):

$$
D=\frac{n i}{A}
$$

Where:

$\mathrm{D} \quad=$ Density of species i (ind/ha)

ni $\quad=$ Total number of individual boxes of species-i

A $\quad=$ Total area of sampling (ha)

The circumference of the mangrove tree trunk was measured at chest height and then converted into trunk diameter, according to Bengen (2001) using the formula:

$$
D B H=\frac{C B H}{\pi}
$$

Where:

DBH = Diameter at Breast Height

$\mathrm{CBH}=$ Circumference at Breast Height

$\pi \quad=3.14$

This value is used to determine basal cover, according to Bengen (2001) using the formula:

Where:

$$
B A=\frac{\pi D B H^{2}}{4}
$$

$\mathrm{BA} \quad=$ Basal Area (area of the base field)

DBH $=$ Diameter at Breast Height

$\pi \quad=3.14$

Tree diameter data is used to calculate tree density and mangrove species important value index.

Mangrove canopy cover was calculated using the hemisperichal photography method (Korhonen et al., 2006; Jennings et al., 1999) using a mobile phone camera (Dharmawan \& Pramudji, 2017). The concept of this analysis is the separation of sky pixels (white) and vegetation cover (black), so that the percentage of mangrove vegetation cover pixels can be calculated in binary image analysis (Chianucci et al., 2014; Ishida, 2004). Photos were analyzed using ImageJ software and Microsoft Excel to calculate the percentage of cover. The average condition of mangrove cover was categorized into three groups, namely dense (>75\%); moderate (between $50-75 \%)$ and rare $(<50 \%)$ based on the Decree of the Minister of the Environment No. 201 of 2004.

The water physicochemical parameters measured in the field (in situ) at each research station were temperature, salinity, and water $\mathrm{pH}$. As for the type of substrate, it is conducted by taking sediment samples using a diameter paralon pipe of $5 \mathrm{~cm}$ with a height of $15 \mathrm{~cm}$. The samples were then taken to the laboratory to determine the grain size of the sediment and the texture of the sediment.

\section{Data Analysis}


The Importance Value Index (IVI) provides an overview of the role of a mangrove species in the ecosystem or to determine the dominance of a species in the community. According to Kusmana et al. (2015) Importance Value Index (IVI) is calculated using the formula:

$$
\mathrm{IVI}=\mathrm{RD}+\mathrm{RF}+\mathrm{RD}
$$

Where:

$\mathrm{RD}($ Relative Density $)=\frac{\text { Density of a species }}{\text { Density of all the species }} \times 100 \%$

$\mathrm{RF}($ Relative Frequency $)=\frac{\text { Frequency of a species }}{\text { Frequency of all the species }} \times 100 \%$

$\mathrm{RD}($ Relative Dominance $)=\frac{\text { Dominance of a species }}{\text { Dominance of all the species }} \times 100 \%$

\section{RESULTS AND DISCUSSION}

\section{A. Environmental Physical and Chemical Parameters}

Temperature plays an important role in the process of photosynthesis and plant respiration, where good mangrove growth requires a minimum air temperature of $>20{ }^{\circ} \mathrm{C}$ (Kusmana et al., 2003). The results of the measurement of waters temperature parameters at the time of observation of mangrove vegetation at all stations ranged from $27-33{ }^{\circ} \mathrm{C}$ (Table 1). This condition shows that the temperature in the waters of Mamuju is still normal in supporting the growth of the mangrove ecosystem and the life of the biota in the area.

Salinity is a factor that greatly determines the development of mangrove forests, especially on the growth rate, resilience and zoning of mangroves. Mangrove vegetation can survive and thrive in estuarine environments with a temperature range of 10-30 \% (Aksornkoae, 1993). The salinity of the waters at all observation stations is on average between 10-30\% (Table 1). The salinity at stations 1, 2, 3 and 5 was lower in the range of 10-25\% due to the regular supply of freshwater from the river flowing through or not far from the observation site. Meanwhile, station 4 , which is located far from the river, has an average salinity of $30 \%$. The salinity range in all these locations is very suitable for mangroves to survive and thrive.

The degree of acidity $(\mathrm{pH})$ also affects the resistance of organisms and enzymatic reactions. The average water $\mathrm{pH}$ measurement at the five observation stations ranged from 7.5-8.2 (Table 1). The $\mathrm{pH}$ range still meets the quality standard for the survival of marine biota based on the Decree of Minister of Environment No. 51 of 2004 where the recommended quality standard is 7-8.5.

Mangroves can grow on sand, mud and coral substrates, but extensive mangroves always grow on muddy soils and are found in areas of deltas, lagoons, bays and estuaries. The type of substrate determines the number of mangrove stands that can grow and develop, because the substrate is related to the oxygen and nutrient content in the sediment. On the sandy substrate there are air pores that allow a more intense mixing with the water above, but the nutrient content in it is lower. The clay substrate has the ability to hold water and has a higher nutrient content. The finer substrate has a higher nutrient content but lower oxygen content (Hardjowigeno, 1992). The results of the analysis of the texture of the substrate at the research site showed that the composition of the sediment texture at all locations did not differ much. Stations 1 and 5 of the substrate type are dominated by sandy clay, station 4 is dominantly clayey, station 2 is sandy loam, and station 3 is clay, and in general the five locations can be overgrown with mangroves.

Table 1. Environmental physical and chemical parameters at the research site

\begin{tabular}{|c|c|c|c|c|c|c|c|}
\hline \multirow{2}{*}{ Station } & \multirow{2}{*}{$\begin{array}{c}\text { Temperature } \\
\left({ }^{\circ} \mathrm{C}\right)\end{array}$} & \multirow{2}{*}{$\begin{array}{c}\text { Salinity } \\
(\%)\end{array}$} & \multirow{2}{*}{$\mathrm{pH}$} & \multicolumn{3}{|c|}{ Texture (\%) } & \multirow{2}{*}{ Substrate Type } \\
\hline & & & & Sand & Dust & Clay & \\
\hline 1 & 29 & 25 & 7.5 & 52 & 8 & 40 & Sandy clay \\
\hline 2 & 27 & 20 & 8 & 59 & 23 & 18 & Sandy loam \\
\hline 3 & 27 & 10 & 7.8 & 40 & 38 & 22 & Loam \\
\hline 4 & 33 & 30 & 7.6 & 36 & 10 & 54 & Clay \\
\hline 5 & 31 & 20 & 8.2 & 49 & 7 & 44 & Sandy clay \\
\hline
\end{tabular}




\section{B. Mangrove Community Structure}

At the research location, 11 (eleven) mangrove species were identified, namely Rhizophora mucronata, Rhizophora apiculata, Rhizophora stylosa, Bruguiera gymnorrhiza, Ceriops tagal, Sonneratia alba, Sonneratia ovate, Avicennia alba, Avicennia marina, Xylocarpus granatum dan Nypa. The highest number of species in the tree category was found at stations 1 and 4 with 6 species, then at station 3 with 5 species and stations 2 and 5 with 4 species (Table 2).

Table 2. Species of found mangroves

\begin{tabular}{|c|c|c|c|c|c|c|}
\hline \multirow{2}{*}{ Family } & \multirow{2}{*}{ Species } & \multicolumn{2}{|c|}{ Bebanga Village } & \multicolumn{2}{|c|}{ Tadui Village } & \multirow{2}{*}{$\begin{array}{l}\text { Bambu } \\
\text { Village } \\
\begin{array}{c}\text { Station } \\
5\end{array}\end{array}$} \\
\hline & & $\begin{array}{c}\text { Station } \\
1\end{array}$ & $\begin{array}{c}\text { Station } \\
2\end{array}$ & $\begin{array}{c}\text { Station } \\
3\end{array}$ & $\begin{array}{c}\text { Station } \\
4\end{array}$ & \\
\hline \multirow{6}{*}{ Rhizophoraceae } & Tree & & & & & \\
\hline & Rhizophora mucronata & $\sqrt{ }$ & & $\sqrt{ }$ & $\sqrt{ }$ & \\
\hline & Rhizophora apiculata & $\sqrt{ }$ & $\sqrt{ }$ & $\sqrt{ }$ & $\sqrt{ }$ & $\sqrt{ }$ \\
\hline & Rhizophora stylosa & $\sqrt{ }$ & & & & \\
\hline & Bruguiera gymnorrhiza & $\sqrt{ }$ & & & & \\
\hline & Ceriops tagal & & & & $\sqrt{ }$ & \\
\hline \multirow[t]{2}{*}{ Sonneratiaceae } & Sonneratia alba & $\sqrt{ }$ & $\sqrt{ }$ & $\sqrt{ }$ & $\sqrt{ }$ & $\sqrt{ }$ \\
\hline & Sonneratia ovata & & & $\sqrt{ }$ & $\sqrt{ }$ & $\sqrt{ }$ \\
\hline \multirow[t]{2}{*}{ Avicenniaceae } & Avicennia alba & & $\sqrt{ }$ & $\sqrt{ }$ & & \\
\hline & Avicennia marina & & & & $\sqrt{ }$ & $\sqrt{ }$ \\
\hline \multirow[t]{2}{*}{ Meliaceae } & Xylocarpus granatum & $\sqrt{ }$ & $\sqrt{ }$ & & & \\
\hline & Sapling & & & & & \\
\hline \multirow[t]{5}{*}{ Rhizophoraceae } & Rhizophora mucronata & $\sqrt{ }$ & & $\sqrt{ }$ & $\sqrt{ }$ & \\
\hline & Rhizophora apiculata & & & $\sqrt{ }$ & $\sqrt{ }$ & \\
\hline & Rhizophora stylosa & $\sqrt{ }$ & & & & \\
\hline & Bruguiera gymnorrhiza & $\sqrt{ }$ & & & & \\
\hline & Ceriops tagal & & & & $\sqrt{ }$ & \\
\hline Sonneratiaceae & Sonneratia alba & & $\sqrt{ }$ & $\sqrt{ }$ & $\sqrt{ }$ & \\
\hline \multirow[t]{2}{*}{ Avicenniaceae } & Avicennia marina & & & & $\sqrt{ }$ & \\
\hline & Seeding & & & & & \\
\hline \multirow[t]{3}{*}{ Rhizophoraceae } & Rhizophora mucronata & $\sqrt{ }$ & & $\sqrt{ }$ & $\sqrt{ }$ & \\
\hline & Rhizophora apiculata & & $\sqrt{ }$ & $\sqrt{ }$ & $\sqrt{ }$ & \\
\hline & Ceriops tagal & & & & $\sqrt{ }$ & \\
\hline \multirow[t]{2}{*}{ Sonneratiaceae } & Sonneratia alba & $\sqrt{ }$ & $\sqrt{ }$ & & $\sqrt{ }$ & \\
\hline & Sonneratia ovata & & & $\sqrt{ }$ & $\sqrt{ }$ & \\
\hline Avicenniaceae & Avicennia marina & & & $\sqrt{ }$ & $\sqrt{ }$ & \\
\hline Arecaceae & Nypa & & & $\sqrt{ }$ & & \\
\hline
\end{tabular}

The structure of the mangrove vegetation found was the same as previously reported that at the tree level there were 6 (six) mangrove species in the village of Bebanga, namely Rhizophora mucronata, Rhizophora apiculata, Sonneratia alba, Avicennia alba, Avicennia marina, dan Bruguiera gymnorrhiza (Syukri et al., 2018 ). Overall, the mangrove community in this area is dominated by Rhizophora spp and Sonneratia spp, as can be seen from the two species found at all observation stations. This is because the species of Rhizophora apiculata and Rhizophora mucronata can grow on muddy, smooth soil and like waters that have a strong influence of permanent freshwater input. Likewise, the types of Sonneratia alba and Sonneratia ovata that grow on muddy soils that are affected by tides (Noor et al., 2012). The species of mangroves that grow in the area are generally due to natural growth, except for some mangrove species Rizhophora spp which are found at station 4 (Bambu Village) which are the result of rehabilitation.

\section{Density and IVI}

The density of mangrove species found at the research site on the coast of Mamuju is divided into three (3) categories, namely trees, saplings and seedlings. In the tree categories, the highest density was found at station 1 of 1633 trees/ha, and station 4 of 1511 trees/ha, which based on the Decree of the Minister of Environment No. 201 of 2004 is in good/very solid criteria. Then at station 3 of the species density is 1100 trees/ha which means it is in 
$\mathrm{good} / \mathrm{medium}$ criteria, the lowest species density is at station 2 of 617 trees/ha and station 5 of 540 trees/ha or is in the damaged/rare criteria (Figure 2 ).

In the sapling category, the density of mangrove species in all research locations is $<1000$ trees/ha (Figure 3). In the seedling category, the highest density of mangrove species was found at stations 1, 4 and 3, while stations 2 and 5 had low density (Figure 4).

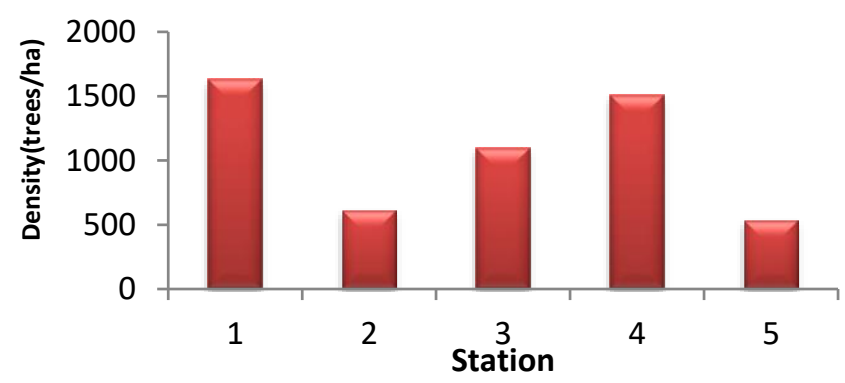

Figure 2. Density of mangrove species for tree categories

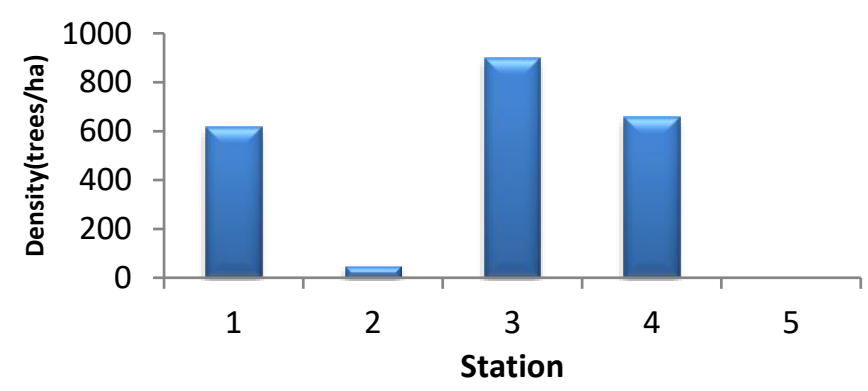

Figure 3. Density of mangrove species for sapling categories

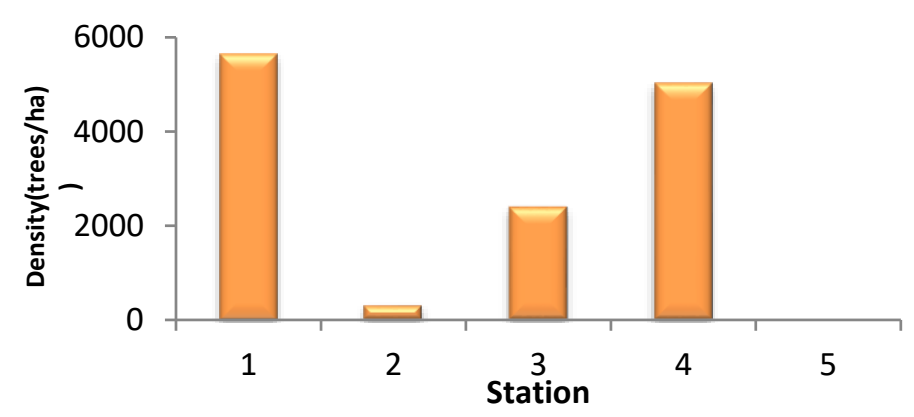

Figure 4. Density of mangrove species for seedling categories

Mangroves for tree, sapling and seedling categories at stations 1 and 4 had the highest total density values compared to other stations and Rhizophora mucronata was the species of mangrove with the highest density in the tree, sapling and seedling phases at both stations. The type of muddy and sandy substrate makes it easy to spread seeds of the Rhizophora mucronata species to grow and develop in that location. Previous research in Banyuwangi Regency found that Rhizophora apiculata, Rhizophora mucronata and Sonneratia alba were the dominant species and their distribution was evenly distributed throughout the coastal area (Sudarmadji et al., 2011). In addition, because the shape of the propagules is large and elongated and has more food reserves, the survival ability of this species is higher.

At station 3, the total density value was moderate, with almost even density between Rhizophora apiculata, Rhizophora mucronata, Sonneratia alba and Avicennia alba. The dominant substrate of clay in the form of thick mud is also a factor in the ease with which the Rhizophora apiculata species grows and develops at station 3. In addition, the location of station 3 is at the main way of the river and is still influenced by tides so that it has a strong influence 
of permanent freshwater input making it easier for Rhizophora mucronata to grow and develop. Sonneratia alba and Avicennia alba are also species that grow and develop well at station 3 because of their location in the estuary and protected from strong waves (Noor et al., 2012).

Stations 2 and 5 have a density level of damaged/rare mangroves. Even the density value at the sapling and seedling level at station 5 is 0 . This is because the location is a residential area and the population activity at that location is quite high.

The Importance Value Index (IVI) is a value that describes the influence or level of dominance of vegetation types in the community or mangrove ecosystem. The composition and number of attendance of each individual at the research location has an influence on the important value (Akbar et al., 2018). At the five research stations there are differences in the IVI values at each station. At stations 1 and 2 Sonneratia alba has the highest IVI, which is 102,48 $\%$ and $125,89 \%$, respectively, at station 3 is Rhizophora apiculata at 132,92\%, at station 4 is Rizophora mucronata at $85,42 \%$ and at station 5 is Sonneratia ovata of $219,29 \%$ which is the highest IVI value at all observation stations (Figure 5).

The high IVI of Sonneratia alba, Sonneratia ovata, Rhizophora apiculata, and Rizophora mucronata at the observation site is due to the high frequency of presence of these species, in addition to the suitable substrate factors for the growth of mangrove species Sonneratia alba, Sonneratia ovata, Rhizophora apiculata, and Rizophora mucronata at the location research. This condition illustrates that the four species of mangroves have a role in developing the mangrove community in the coastal area of Mamuju.

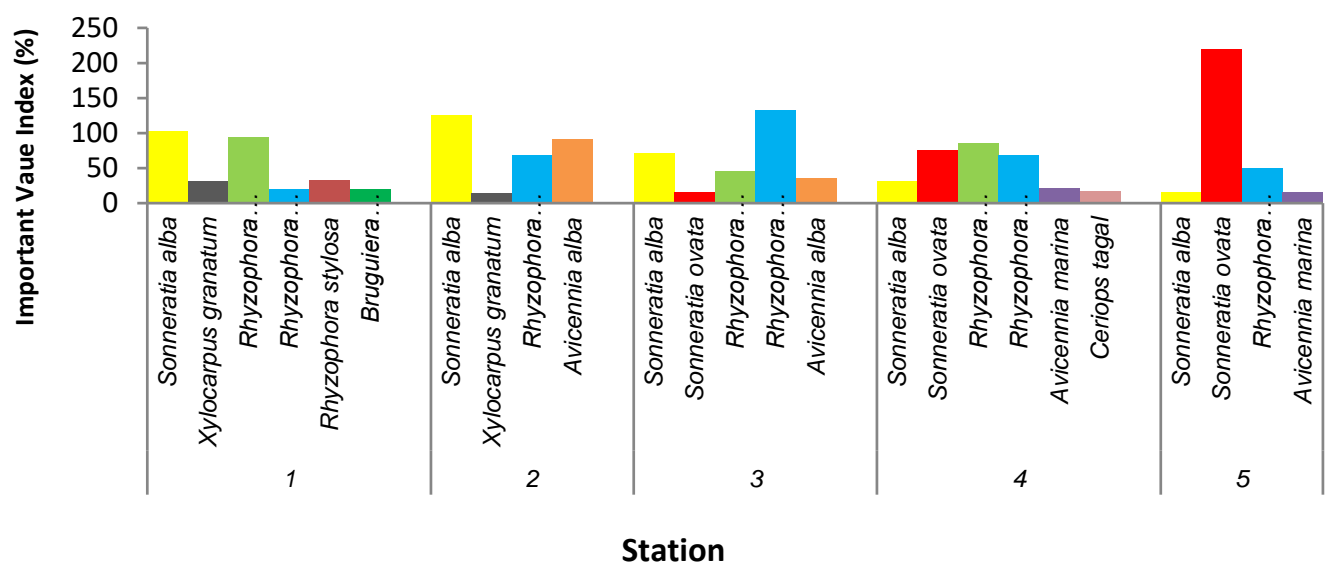

Figure 5. Important Value Index (IVI) for tree categories

\section{Mangrove Canopy Cover}

From the observation of mangrove canopy cover, it was found that the condition of mangrove cover at stations 1,3 and 4 was in good criteria (very dense) or $>75 \%$, while at stations 2 and 5 it was damaged (rare) or a value of < $50 \%$ based on criteria from the Ministry of Environment. No. 201 of 2004. The highest percentage of canopy cover was at station $1(84.14 \%)$ and station $3(82.64 \%)$, while the lowest percentage was at station $2(48.24 \%)$ (Figure 6).

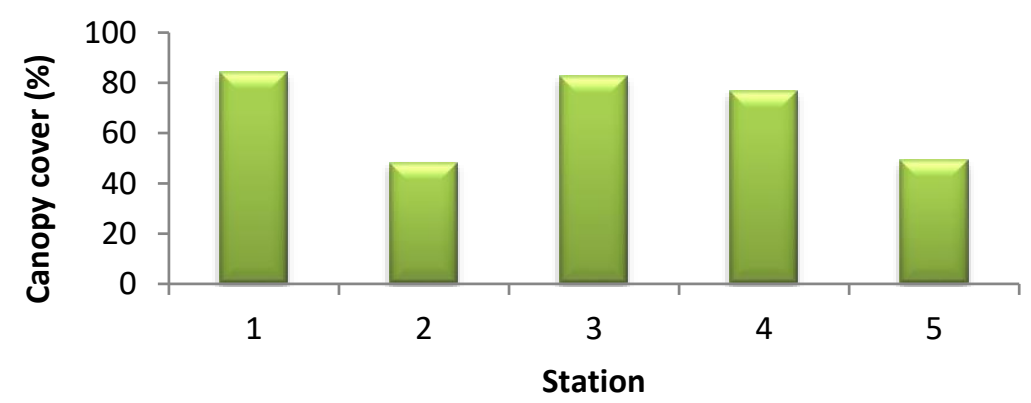

Figure 6. Mangrove canopy cover 
The high percentage of cover at stations 1, 3 and 4 indicates that the condition of the mangrove ecosystem in the village of Bebanga and Village of Tadui is in good condition. The high canopy cover is thought to be due to fit and suitable environmental conditions for mangrove growth. In addition, the awareness of the surrounding community that protects the mangrove forest from illegal logging has caused the mangrove community to grow densely.

The high percentage of coverage at stations 1 and 4 is supported by the high density values at both stations. While the percentage of cover at station 3 is higher than at station 4 even though the density value of station 3 is in the medium category. This is presumably because the mangrove communities at stations 1 and 3 are old mangroves that can be seen from the tree height and bigger trunk circumference, as well as dense leaves. Meanwhile, at stations 2 and 5 , the percentage of canopy cover was in the rare category, which was $<50 \%$ in line with the level of density and the number of trees which were also low. This is due to the fact that this station is quite close to residential areas and human activities are quite high, thus disrupting the growth of mangroves.

\section{CONCLUSION}

Mangrove species in the eastern coastal area of Mamuju Regency are still very high, namely 11 species from 5 families, namely Rhizophoraceae, Sonneratiaceae, Avicenniaceae, Meliaceae, and Arecaceae. Rhizophora apiculata and Sonneratia alba were mangrove species found in all research sites, while the species with the highest IVI were Sonneratia alba, Sonneratia ovata, Rhizophora apiculata and Rizophora mucronata. Based on the density analysis, the mangrove conditions in the research area were categorized as rare, medium and very dense, while based on the canopy cover analysis, the mangrove conditions were categorized as rare and very dense.

\section{BIBLIOGRAPHY}

Akbar, N., Ibrahim, A., Haji, I., Tahir, I., Ismail, F., Ahmad, M., \& Kotta, R. (2018). Mangrove Community Structure in Tewe Village, South Jailolo District, West Halmahera Regency, North Maluku Province. Enggano Journal, 3(1), 81-97. https://doi.org/10.31186/jenggano.3.1.81-97

Aksornkoae S. (1993). Ecology and management of mangroves. Bangkok: IUCN.

Atkinson, S. C., Jupiter, S. D., Adams, V. M., Ingram, J. C., Narayan, S., Klein, C. J., \& Possingham, H. P. (2016). Prioritising mangrove ecosystem services results in spatially variable management priorities. PLoS ONE, 11(3), 1-21. https://doi.org/10.1371/journal.pone.0151992

Bengen, D. G. (2001). Technical Guidelines for the Introduction and Management of Mangrove Ecosystems. Bogor: PKSPL-IPB.

Chianucci, F., Chiavetta, U., \& Cutini, A. (2014). The estimation of canopy attributes from digital cover photography by two different image analysis methods. IForest, 7(4), 255-259. https://doi.org/10.3832/ifor0939-007

Department of Marine Affairs and Fisheries of West Sulawesi Province. (2017a). Final Document of Zoning Plan for Coastal Zone and Islets (RZWP-3-K) of West Sulawesi Province.

Department of Marine Affairs and Fisheries of West Sulawesi Province. (2017b). Final Report of the Zoning Plan for Coastal Zone and Islets (RZWP-3-K) of West Sulawesi Province.

Dharmawan, I. W. E., \& Pramudji. (2017). Mangrove Community Monitoring Guide. In Critc Coremap Cti Lipi.

English, S., Wilkinson, C., \& Baker, V. (1994). Survey manual for tropical marine resource. TownIVIlle, Australian Institute of Marin Science.

Ghosh S, Bakshi M , Bhattacharyya S, N. B. and C. P. (2015). A Review of Threats and Vulnerabilities to Mangrove Habitats: With Special Emphasis on East Coast of India. Journal of Earth Science \& Climatic Change, 06(04). https://doi.org/10.4172/2157-7617.1000270

Hardjowigeno, S. (1992). Soil Science (The $3^{\text {rd }}$ Edition). Jakarta: PT Mediyatama Sarana Perkasa.

Ishida, M. (2004). Automatic thresholding for digital hemispherical photography. Canadian Journal of Forest Research, 34(11), 2208-2216. https://doi.org/10.1139/X04-103

Jennings, S. B., Brown, N. D., \& Sheil, D. (1999). Assessing forest canopies and understorey illumination: Canopy closure, canopy cover and other measures. Forestry, 72(1), 59-73. https://doi.org/10.1093/forestry/72.1.59

This publication is licensed under Creative Commons Attribution CC BY.

http://dx.doi.org/10.29322/IJSRP.11.07.2021.p11556

wWw.ijsrp.org 
ISSN 2250-3153

Kamal, E., \& Haris, N. (2014). Composition and Vegetation of Mangrove Forests in Islets, West Pasaman. Marine Science, 19(2), 113-120.

Korhonen, L., Korhonen, K. T., Rautiainen, M., \& Stenberg, P. (2006). Estimation of Forest Canopy Cover : a Comparison of Field Measurement Techniques. Silva Fennica, 40(4), 577-588.

Kusmana, C., I. Setyobudiandi, S. Hariyadi, A. S. (2015). Sampling and Bioecological Analysis of Coastal and Marine Biological Resources. Bogor: IPB Press.

Kusmana C, Wilarso S, Hilwan I, Pamoengkas P, Wibowo C, Tiryana T, T., \& A, Y. \& H. (2003). Mangrove Rehabilitation Techniques. Bogor: Faculty of Forestry. IPB. Bogor.

Lasibani, S. M., \& Kamal, E. (2010). Distribution Pattern of Growth of Rhozophoraceae Mangrove Propagules in Coastal Areas of West Sumatra. Journal of Mangroves and Coasts, 10(1), 33-38.

Mumby, P. J., Edwards, A. J., Arias-Gonzalez, J. E., Lindeman, K. C., Blackwell, P. G., Gall, A., ... Llewellyn, G. (2003). Mangroves enhance the biomass of coral reef fish communities in the Caribbean. Journal of Geophysical Research: Solid Earth, 108(B5). https://doi.org/10.1029/2001jb001194

Muryani, C., Ahmad, Nugraha, S., \& Utami, T. (2011). Community Empowerment Model in Mangrove Forest Management and Conservation on Pasuruan Beach, East Java. Journal of Humans and the Environment, $18(2), 75-84$.

Noor, Y. R., Khazali, M., \& Suryadiputra, I. N. N. (2012). Guide to Introduction to Mangroves in Indonesia.

Polidoro, B. A., Carpenter, K. E., Collins, L., Duke, N. C., Ellison, A. M., Ellison, J. C., .. Yong, J. W. H. (2010). The loss of species: Mangrove extinction risk and geographic areas of global concern. PLoS ONE, 5(4). https://doi.org/10.1371/journal.pone.0010095

Septinus, M., Kurnia, R., \& Pratiwi, N. T. M. (2017). Land Changes and Management Strategies of Mangrove in Sawo District, North Nias Regency, North Sumatra Province. Land Changes and Management Strategies of Mangrove in Sawo District, North Nias Regency, North Sumatera Province. Jurnal Ilmu Dan Teknologi Kelautan Tropis, 9(2), 499-506.

Sofian, A., Kusmana, C., Fauzi, A., \& Rusdiana, O. (2019). Service ecosystems based on mangrove management strategies in Indonesia: an overview. AACL Bioflux, 12(1), 151-166.

Sofia. (2001). Decentralized Management of Coastal and Ocean Resources. A Challenge and an Opportunity. Bogor Agricultural University.

Sudarmadji and Indarto. (2011). Identification of Land and Mangrove Forest Potential in the Eastern Part of East Java Province. Bonorowo Wetlands, 1(1), 7-13.

Syukri, M., Mashoreng, S., Werorilangi, S., Isyrini, R., Rastina, Faizal, A., ... Gosalam, S. (2018). Study of Mangrove Carbon Stock in Bebanga, Mamuju Regency, West Sulawesi. Carbon Stock Analysis of Mangroves in Bebanga, Mamuju Regency, West Sulawesi. Proceedings of the 5th National Symposium on Maritime Affairs and Fisheries, Hasanuddin University, Makassar, 5 May 2018, 335-342.

Utomo, B., Budiastuty, S., \& Muryani, C. (2017). Mangrove Forest Management Strategy in Tanggul Tlare Village, Kedung District, Jepara Regency. Journal of Environmental Science, 15(2), 117-123. https://doi.org/10.14710/jil.15.2.117-123 